\title{
Investigating Impact of Parental Motivations and Involvement within a Developing Country
}

Michael Asamani POBBI

Accra Technical University

Ghana

\begin{abstract}
This research investigated the effects of attitude and beliefs, subjective norms, and perceived behavioural control on parents' home-based and school-based involvement in child education. The paper reports quantitative findings from a cross-sectional survey based on a concurrent mixed design. Primary data was collected from five hundred and sixty (560) parents who were selected randomly from deprived and non-deprived districts across six regions of Ghana. The Cronbach $\alpha$ of reliability for attitude and belief, perceived behavioural control, subjective norm, home-based and school-based involvement exceeded the minimum threshold. Results from structural equation modelling analysis based on a bootstrapping technique reveal that the model of the study was confirmed, as the data showed equivalence to model assessment measures including CFI $=0.979, \mathrm{TLI}=0.975, \mathrm{GFI}=0.942, \mathrm{AGFI}=0.922, \mathrm{RMSEA}=0.049$, $\chi 2 / \mathrm{df}=2.292$. The finding of the study indicated that attitude and beliefs, subjective norms, perceived behavioural control of parents significantly impact home-based involvement, whiles perceived behavioural control and subjective norms of parents had significantly impact on school-based involvement.
\end{abstract}

Keywords: parent attitudes; perceived behavioural control; subjective norms; school-based involvement

\section{Introduction}

Parental Involvement toward the performance of children is regarded by many policy makers and practitioners as vital toward the development of the child in school and thereafter. In recent years, the phenomenon of parental involvement has been "advertised" in the western world as a nearly-globally accepted "vehicle" for the success of children's education, especially at the lower levels of educational and, thus, regarded as a key parameter of educational quality. The concept of Parental Involvement in education has become a primary focus of educational policies and reforms in several developed countries (Miksic, 2015). 
Mungai (2015) posits that the notion created about parental involvement is somewhat different in less developed nations, particularly in Africa, where this "advertised" parameter of educational quality happens to be amongst the least understood. Contrary to this new wave of transformation in educational policies across the globe, a snapshot of major educational initiatives and policies undertaking in less developed nations in Africa, including Ghana, have not given much attention to the role that parental involvement can play in achieving quality education (Vanderpuye, 2013; Mungai, 2015; Gyamfi and Pobbi, 2016). For example, the Ghana Education Service Act, 1995 (Act 506) as part of Ghana's decentralisation policy emphasizes a collaborative approach in which all stakeholders including Parents and Teachers Association(PTA) have spell-out roles and responsibilities in the planning process. Although the Act (Act 506) is supposed to encourage active community participation and for that matter active participation of parents in their children's education there is no clear policy document on parental involvement nationally, or at the school level (Vanderpuye, 2013). Ghanaian studies including Pryor and Ampah (2003), Nyarko (2011), Chowa, Masa, and Tucker (2013); Gyamfi and Pobbi $(2016$; 2018) have attested to the lack of interest by most Ghanaian parents in the education of their children. The situation is worrying as studies including Eisenberg and Wolchik (1992), and Jeynes (2007; 2011) have shown that the competences and performance of children at the basic school, are heavily associated with the parents' involvement.

Aside the lack of strategic policy direction three key issues: societal perceptions of education, beliefs and relevance placed on education, and the ability of parents to engage in relevant educational activities have been identified to affect the involvement level of parents in less developed countries. These issues, conceptualised as subjective norms, attitude and beliefs, and perceived behavioural control in this study, according to Donkor (2010) and Pobbi (2020) contribute to motivating or demotivating parents' interest to be involved in their child's education. With regard to the attitude and belief of parents, some studies have shown that some parents, especially in deprived areas, still do not see the relevance of their children education (Uemura, 1999; GSS, 2016). Again negative perceptions and cultural beliefs held by the people in the community relating education demotivates them in their support for children enrolled in school (Donkor, Issaka, and Asante, 2013; Yeboah, 2013; Pobbi, 2020). Pobbi (2020) also highlighted that the lack of knowledge did limit parents' involvement in school activities and even in some home-based activities. The effect of these three issues on parental involvement appears to be more pronounced in the deprived districts in less developed countries (Uemura, 1999; Pobbi, 2020). 
Some valid questions which emanate within the less developing country context which this research addressed were: what factors effectively motivate parents to actively engage in the education of their children? To what extent do these motivational factors influence parents' level of involvement? This study, guided by Alghazo's (2013) Theory of Planned Behaviour and Parental Involvement, and Hoover-Dempsey Dempsey, and Sandler (1997) Parental motivation model, sought to address these gaps in extant knowledge on Parental Involvement. An exploration of motivational factors which influence involvement of parents in less developed countries, contribute to existing knowledge by revising and extending existing theories including Hoover Dempsey and Sandler (1997).

\section{Literature Review}

Theoretical background and hypotheses development

Two literatures inform this study: Alghazo's (2013) Theory of Planned Behaviour and Parental Involvement and Hoover-Dempsey et al. (1997) Parental motivation model. According to Green, Walker, Hoover-Dempsey, and Sandler (2007), three major sources of motivation are responsible for involvement. These are parents' motivational beliefs relevant to involvement, parents' perceptions of invitations to involvement, and parents' perceptions of the forms and timing of involvement that seem feasible (Green et al., 2007).

Parents' motivational beliefs relevant to involvement, According to Hoover-Dempsey et al. (2005), included two factors; parental role construction and parental self-efficacy for helping the child succeed in school. The next source of motivation is parents' perceptions of involvement invitations from the school, teachers and child. These forms of invitations from the school, teachers and child are to an extent interrelated and help to enhance family engagement in children's schooling (Epstein, Sanders, Simon, Salinas, and Voorhis, 2012). For example parents interpret teacher invitations as a way of teacher's expressing the relevance of parents' contributions to their child's educational success (Green et al., 2007; Strickland, 2015). Personal life context variables involve parents' skills and knowledge for involvement and influence parents' perceptions of the forms and timing of involvement that seem feasiblem(Green et al., 2007). 
Green et al. (2007) model failed to capture two relevant factors known to influence parents desire to engage in either school-based activities or home-based activities within less developed countries. These are the subjective norms (Donkor, 2010; Donkor et al., 2013; Yeboah, 2013; Pobbi, 2020), and the attitude and beliefs of parents (Pobbi, 2020), regarding the education of their children. The Ghana Statistical Service Labour Force report (2016) corroborates this fact, as it outlined that some reasons why parents would not enrol their child in school were that: education was not considered as important or valuable parents; parents preferred that their children worked as unpaid worker in family business/farm; and family just did not allow schooling. Bracke and Corts (2012) adds that parental role in child education, are shaped by the way their neighbours get involved in their children's education.

As an alternative theory to help explain and predict Parental Involvement in less developed, consistent with Perry and Langley (2013), Alghazo (2013) conceptual framework of Planned Behaviour and Parental Involvement is adopted for investigation in this study. Alghazo (2013), framework is underpinned by Ajzen's (1991) Theory of Planned Behaviour (TPB) and Bandura (1997) study sought to provide a theoretical support that links parental involvement to parent abilities and perceptions, and societal factors which has been an outstanding gap in earlier Parental Involvement theories. It is also worth noting that the Alghazo's Theory of Planned behaviour and Parental Involvement was only conceptualized and hence lacked empirical evidence to support the relationships suggested by the model. The present research based on this framework provides empirical evidence of its applicability within a developing country context.

\section{Empirical Review}

Extant literature including Green et al. (2007) and Strickland (2015) sought to provide empirical basis for Hoover-Dempsey and Sandler (1997) using data from urban communities in developed countries. Green et al. (2007) examined the relevance of three motivation factors which included parents' motivational beliefs, perceptions of invitations to involvement, and perceived life context toward explaining. Multiple hierarchical regressions using data from elementary school parents the revealed that predictor variables accounted $27 \%$ of the variance of home-based involvement and $47 \%$ of the variance of school-based involvement. Additionally, the researchers found that general invitations to involvement from the school, specific teacher invitations, and self-perceived skills and knowledge were not significant predictors of both home-based involvement and School-Based Involvement. 
Strickland (2015), similar to Green et al. (2007), adopted Hoover-Dempsey and Sandler (1997) theoretical framework for investigating motivations to parental involvement. The results of Strickland (2015), to an extent, contradicted the findings of Green et al. (2007). In Strickland (2015) study the researcher found that Personal motivations did not have significant effect on both home and school involvement behaviours. However, strong effect was found for invitations on school-based involvement whereas the moderate positive effect was observed for home-based involvement behaviours. Life context was found to have moderate positive effect on home-based involvement only. The coefficient of determination in home-based behaviours $\left(\mathrm{R}^{2}=0.238\right)$ and school-based involvement $\left(\mathrm{R}^{2}=0.225\right)$ models were, did not differ much from that of Walker et al. (2005). An important point raised by the Strickland (2015) was the need for a context specific approach to addressing involvement.

The factors highlighted by Strickland (2015) as components of parental motivation, although, important do not reflect parental motivations within the developing world context, thus, leaving a gap in existing literature (Avvisati, Gurgand, Guyon, and Maurin, 2014; Pobbi, 2020). Studies including Avvisati, Besbas, and Guyon (2010), Avvisati et al. (2014) point out the need for a developing country context specific finding as they argue that culture in developed countries varies from that in less developed countries and this could influence the beliefs and attitudes of parents. Ghanaian studies and reports including Pryor and Ampiah (2003), Ghana Statistical Service (2016), and Pobbi (2020), highlight the perception of parents regarding the relevance of child education as an integral factor which influence parent decision to be involved either at home or at school. Donkor (2010) also study found that positive parental value of education in a less developed country was influenced by the parents' awareness of the relationship between education and the future economic well-being of their children. This fact is corroborated by Brooke (2009) and Pobbi (2020).

Pobbi (2020) highlights the need to address the question of what effectively motivates parents in developing countries to actively engage in the education of their children. Pobbi (2020) study concluded that three main factors including parent's Attitude and belief, Perceived behavioural control (PBC) and Social norm (SN) are relevant toward explaining parental motivations of parents in developing country. However, studies including Pryor and Ampah (2003), Donkor (2010), Yeboah (2013) and Pobbi (2020) which have outlined some of the three motivations for involvement in less developed countries have failed to provide rigorous evidence on how 
motivational factors do influence involvement of parents and subsequently the performance of children in less developed country context.

Based on the discussions above the following, hypotheses are formulated for investigation:

$\mathrm{H}_{1 \mathrm{a}}$. Attitudes and beliefs of parents does influence home-based Involvement towards child education.

$\mathrm{H}_{1 \mathrm{~b}}$. Attitudes and beliefs of parents does influence school-based Involvement towards child education.

$\mathrm{H}_{3 a}$. Subjective norms of parents does significantly influence home-based Involvement towards child education.

$\mathrm{H}_{3 \mathrm{~b}}$. Subjective norms of parents does significantly influence school-based Involvement towards child education.

$\mathrm{H}_{2 \mathrm{a}}$. Perceived behavioural control of parents does influence home-based Involvement towards child education.

$\mathrm{H}_{2 \mathrm{~b}}$. Perceived behavioural control of parents does influence school-based Involvement towards child education.

\section{Methodology}

\section{Instrument development}

In order to improve content validity, measurement items for the research model were adapted from literature. The six (6) Items on attitude and belief, six items on subjective norms, and five items for perceived behavioural control were selected from sources including Ajzen (1991), Green et al. (2005), Bandura, Adams, Hardy, and Howells (1980). Seventeen (17) items for home-base involvement and six items for school-based involvement were also selected from sources including Epstein and Sanders (2002), Walker et al. (2007), Cho and Han (2004), Gyamfi and Pobbi (2016). The items were reworded to reflect the context of study. To ensure the quality of the survey questions, senior researchers with expertise on the subject matter first reviewed the questionnaire to ensure that it was meaningfully. Results from an exploratory factor analysis suggested that the instrument had good validity. All measurement items were presented in measured using a 5-point Likert scale ranging from strongly disagree (1) to strongly agree (5) for measures of three constructs and never (1) to always (5) for HBI and SBI. 
Sample and data collection

Collection of data for the study begun in June, 2019 to August 2019 across six regions in Ghana. Prior to data collection, the researcher sent letters of introduction form the Institution of study (AIT) to all the District Educational offices and Headteachers of participating schools for their consent.

The researcher with the help of trained data collection personnel and class teachers administered the questionnaires in the various schools. Parents of children selected for the study were invited by class teachers. Upon arrival the researcher assured anonymity and confidentiality of responses provided by respondent, offered a better explanation on the purpose of the study and the items of the questionnaire. As it was assumed that a parent of child in school has one child in school, only one parent filled out a questionnaire per child. If the family had more than one child, they were asked to fill out a questionnaire only for the child who was selected during sampling. Out of a total of 560 questionnaires administered 13 incomplete questionnaires were dropped. Of the valid responses, 54.3\% were from nondeprived districts and $45.7 \%$ were from deprived districts.

Table 1 shows the detailed sample demographics of our respondents.

\section{Data analysis and results}

Data collected was analysed using the structural equation modelling (SEM) using SPSS Amos version 21. Aggregated measure of home-base and school-based was used in analysis. Following the two-step approach for evaluating structural equation models recommended by Chin (1998), the researcher first examined the measurement model to evaluate the instrument's reliability and validity properties. Next, path analysis was conducted to test proposed relationship among variables in this study. Parameters during SEM were estimated using a resampling approach (bootstrap), since it lacks the classical parametric inferential framework (Wold, 1982) and less restrictive on residual distribution restrictions than are found in other analysis models (Chin, Marcolin, and Newsted, 2003).

Table 1.Demographic information of the sample.

\begin{tabular}{lcc}
\hline Variable & Response & Percentage \\
\hline District type & Deprived & 45.7
\end{tabular}




\begin{tabular}{llr} 
& Non deprived & 54.3 \\
Relationship with child & Father & 38.5 \\
& Mother & 53.0 \\
& Guardian & 6.9 \\
Education level of Parent & Other & 1.7 \\
& None & 10.6 \\
& Basic & 38.3 \\
& Secondary & 34.6 \\
& Tertiary & 16.5 \\
\hline
\end{tabular}

Measurement model

Reliability of constructs was assessed using Cronbach's alpha and composite reliability measures to test the internal consistency of the model. As displayed in Table 2, each construct's Cronbach's alpha and composite reliability values exceeded the acceptable level of 0.7 recommended by Hair, Black, Babin, Anderson, and Tatham (2006). In line with Bagozzi and Yi (1988) recommendation, convergent validity of the model was assessed using two standards: (1) average variance extracted (AVE) for each variable should exceed 0.5 (Fornell and Larcker, 1981) and (2) indicator factor loadings which have a minimum threshold of 0.5 (Hair et al., 2006). Evidence of convergent validity of the research instrument in presented in Table 2.

Table 2. Results of convergent validity testing.

\begin{tabular}{lrrrrrl}
\hline & ATT & PBC & SN & CA & CR & AVE \\
\hline ATT1 & 0.887 & & & 0.969 & 0.976 & 0.839 \\
ATT2 & 0.924 & & & & & \\
ATT3 & 0.933 & & & & & \\
ATT4 & 0.930 & & & & & \\
ATT5 & 0.920 & & & & & \\
ATT6 & 0.902 & & & & & \\
PBC1 & & 0.735 & & & & \\
PBC2 & & 0.782 & & & & \\
PBC3 & & 0.793 & & & \\
PBC4 & & 0.782 & & 0.869 & 0.878 & 0.750 \\
PBC5 & & 0.656 & & & & \\
SN1 & & & 0.769 & & & \\
SN2 & & & 0.785 & & & \\
SN3 & & & 0.897 & & & \\
SN4 & & & 0.812 & 0.920 & 0.918 & 0.805 \\
SN5 & & & 0.864 & & & \\
SN6 & & 0.705 & & & \\
\hline
\end{tabular}

To assess discriminant validity, the following guidelines were followed: (1) the FornellLarcker criterion, which states that the AVE of each latent construct should be greater than the highest squared correlations between any other construct (Fornell , and Larcker, 1981), and (2) 
the loadings of each indicator should be greater than all its cross loadings (Chin, 1998). An inspection of indicator cross loadings in Table 2 reveals that all indicators load their highest on their respective construct and that no indicator loads higher on other constructs than on its intended construct.

As is evident in Table 3, that the square root of the AVEs for each construct is greater than the cross-correlation with other constructs. Based on these results, the discriminant validity of the instrument was established.

Table 3.Discriminant validity using Fornell-Larcker Criterion.

\begin{tabular}{lccc}
\hline & SN & PBC & ATT \\
\hline SN & 0.897 & & \\
PBC & 0.551 & 0.866 & \\
ATT & 0.465 & 0.496 & 0.916 \\
\hline
\end{tabular}

Notes: off-diagonals values are inter-construct correlations and diagonal values represent square roots of AVE.

\section{Structural model}

Once the psychometric properties of the measurement model were met, the structural model was examined based on the magnitude, sign, and significance of path coefficients of each path. A standard bootstrapping procedure with 5000 resamples drawn with replacement, was employed to determine the significance of each estimated path.

Model validity was then assessed in terms of the Chi Square with the corresponding p value, the Root Mean Square Error of Approximation (RMSEA) (Byrne, 2013). In addition to the incremental fit indices; The Goodness of fit test index (GFI) and the Comparative fit index (CFI) and Tucker Lewis index (TLI) are utilized for fit evaluation of model validity in this study. Results for the structural model assessment are presented in Table 4 and Figure 1.

Table 4. Path coefficients and their significance and model validity assessment

\begin{tabular}{lllllll}
\hline $\begin{array}{l}\text { Hypothes } \\
\text { es }\end{array}$ & Path & & $\begin{array}{c}\text { Standardised } \\
\text { path } \\
\text { coefficient }\end{array}$ & $\begin{array}{c}\text { p } \\
\text { value }\end{array}$ & \\
\hline $\mathrm{H}_{1 \mathrm{a}}$ & HBI & $<---$ & ATT & 0.363 & 0.000 & Sesult \\
$\mathrm{H}_{2 \mathrm{a}}$ & HBI & $<---$ & PBC & 0.353 & 0.000 & Supported \\
$\mathrm{H}_{3 \mathrm{a}}$ & HBI & $<---$ & SN & 0.146 & 0.000 & Supported
\end{tabular}




\begin{tabular}{lllllll}
$\mathrm{H}_{2 \mathrm{~b}}$ & SBI & $<---$ & PBC & 0.339 & 0.000 & Supported \\
$\mathrm{H}_{3 \mathrm{~b}}$ & SBI & $<--$ & SN & 0.289 & 0.000 & Supported \\
$\mathrm{H}_{1 \mathrm{~b}}$ & SBI & $<---$ & AT & 0.026 & 0.561 & $\begin{array}{l}\text { Not } \\
\text { Supported }\end{array}$ \\
\hline $\begin{array}{l}\text { CMIN/ } \\
\text { DF }\end{array}$ & GFI & & AGFI & TLI & CFI & RMSEA \\
\hline 2.292 & .942 & & .922 & .975 & .979 & 0.49 \\
\hline
\end{tabular}

It was found that attitudes and beliefs $(\beta=0.363$, $p$ value $=0.000)$, subjective norms $(\beta=0.146$, $\mathrm{p}$ value $=0.001)$, perceived behavioural control $(\beta=0.353, \mathrm{p}$ value $=0.00)$ had significant effect on home-based involvement. It was also found that only perceived behavioural control $(\beta=0.339, \mathrm{p}$ value $=0.00)$ and subjective norms of parents $(\beta=0.289, \mathrm{p}$ value $=0.000)$ had significant effect on school-based involvement.

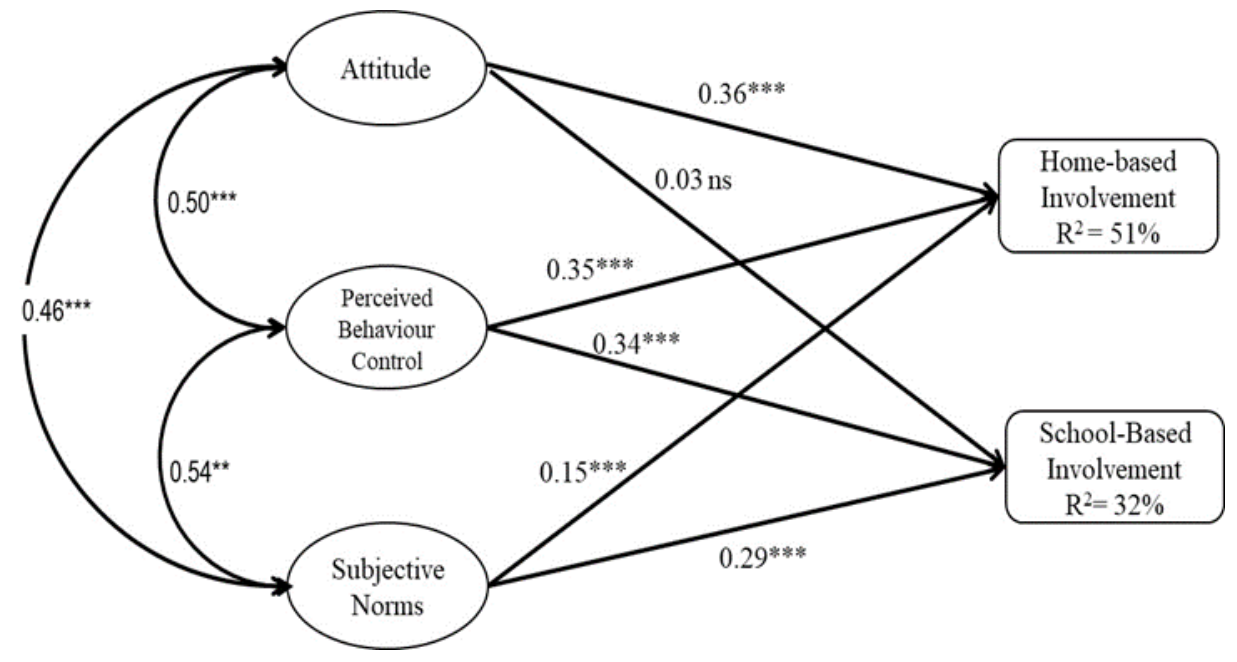

Figure 1. Empirical model of the study

Predictive validity of the research model is evaluated using the variance explained $\left(\mathrm{R}^{2}\right)$, as the central criterion for assessing the structural model (Henseler, Ringle, and Sarstedt, 2012). It was found that home-based involvement (HBI) had an $\mathrm{R}^{2}$ value of $51.1 \%$. This result implying that the three motivational constructs explain about $51 \%$ percent of the variance in HBI. It was also found that $32.3 \%$ in School-Based involvement was explained by the predictors. These values suggest good predictive and explanatory power of the model. Moreover, the overall model fit measures including $\mathrm{X}^{2} / \mathrm{df}=2.292, \mathrm{GFI}=0.942, \mathrm{AGFI}=0.922, \mathrm{TLI}=0.975$, and $\mathrm{CFI}$ 
$=0.979$ indicate a good model fit. Again the RMSEA $=0.490$ also indicated a good fit model (Byrne, 2013).

\section{Discussion and implications}

Although numerous studies including (Epstein and Sanders, 2002), Hoover-Dempsey and Sandler (1997), Hoover-Dempsey et al. (2005), Nyarko (2011), Chowa et al. (2013), Pobbi (2016) exist, these studies have focussed attention on the relevance of parental involvement on child academic achievement. There is, therefore, very little empirical studies which examine the motivations of parental involvement (Walker et al., 2007, Strickland 2015). Also motivational factors outlined by Walker et al. (2007), Strickland (2015) may not reflect motivation measures in less developed countries, thus, leaving a contextual gap in existing literature. Again the few related studies including Pryor and Ampah (2003), Donkor (2010), Yeboah (2013) and Pobbi (2020), which have outlined some of the three motivations for involvement in less developed countries, have failed to provide rigorous evidence on how motivational factors do influence involvement of parents and subsequently the performance of children in less developed country context.

By developing psychometric measures for measuring parental motivation and also investigating the effects of these constructs on parental involvement in Ghana, this study adds insight into the existing literature by offering a better theoretical understanding of parental involvement in the African context. Out of six relationships hypothesised and tested five of these paths hypothesised, were supported by data as the model satisfied all model assessment measures.

Attitude of parents was found to be the most important predictor of home-based parental involvement. The finding of the study is supported by Green et al. (2007), Alghazo (2013), and Bruning et al. (2004). Hoover-Dempsey et al. (2005) suggested that parents make involvement decisions based on their thinking about the outcomes which are likely to follow their involvement activities. The findings of the study are also consistent with Brooke (2009), Donkor (2010) and Pobbi (2020) also found that positive parental value of education in a less developed country is contingent upon parents' awareness of the connection between education and the future economic well-being of their children. 
As a practical measure schools can share experiences of parental commitment of role models in society and their impact on their children education during Parent and Teacher Association meetings. By so doing parents will be more informed on the relevance of their involvement. Communication will also facilitate a cooperation and shared vision with parents, which will lead to parents dedicating more time and resources toward their children's education.

It was also found that subjective norms had a significant effect on home-based involvement and school-based involvement as hypothesised in prior studies (Avvisati et al., 2010; Bracke and Corts, 2012, Avvisati et al., 2014). The finding again provides empirical evidence support to Donkor et al. (2013). Yeboah (2013) claimed that that negative perceptions and cultural beliefs held by the people in the community demotivates their engagement in child education.

The finding also point to the fact that pressure amounting from expectations of child's school and teachers to ensure that homework is done at home, and also for parent participate in school activities like PTA lead parents to get involved both at home and school was necessary for defining parent subjective norms. This finding is consistent with Epstein et al. (2012), Green et al. (2007), and Strickland (2015) who posit that specific invitations from the child school and from the child also serve as social influence on parents to get involved in the child's education but contradict results from Green et al. (2007).

These finding practically imply that schools leaders must create a welcoming school climate for parents in order to increase collaboration between schools and parents. In this regard, Schools and teachers' must provide positive comments on parent's participation, and providing feedback on child performances to parents, create an environment which will foster questions, comments and controlled visitation from parents. Schools leaders can, by means of continuous professional development, enhance teachers' knowledge and confidence to engage parent in some schooling activities

Consistent with Bandura (1977), Hoover-Dempsey and Sandler (2005), Pena (2000), Smith, Stern, and Shatrova (2008), Jafarov (2015), it was also found in this study that perceived behavioural control had a significant effect on home-based involvement and school-based involvement. The finding of the study, however, contradict that of Green et al. (2007). Bandura (1977) posit that for parents to involve themselves in the education of their children both at school and at home that they must possess expertise or experience needful to perform a task in 
some educational activities. Marschall and Shah (2014), however, warned that in the absence of information or understanding of what is expected of them, even parents with high perceived behavioural control may not involve themselves in some activities, and hence schools must ensure effective communication with all parents. This finding practically imply that schools must improve on communicating their expectations to parents in order to keep them informed on what is expected of them through means including short message service, emails and letters.

These three factors can be improved by improved through sensitisation of parents on the importance of their involvement. School programmes and Parent Teacher Association (PTA) meeting should focus attention on educative programmes for parents, especially in deprived districts, targeted at sensitizing parents and communities on the relevance of parent involvement toward their children's performances, self-confidence in school, and better future after school.

\section{Limitations and future research directions}

Despite the study's findings and implications, our study does contain some limitations. First, the cross-sectional nature of the analysis can only provide the associative relationships between the stated constructs. Future research should use a longitudinal study to address the causal relationships between the constructs over time. Secondly, the context of our study may have constrained generalisation with respect to cultural context and may not reflect of factors in developed countries. As this study did not specifically examine involvement for parents of disabled population or form migrating parents within developing countries, further research can be advanced in this direction.

\section{Disclosure statement}

No potential conflict of interest was reported by the author.

\section{References}

Ajzen, I. (1991). The theory of planned behavior. Organizational Behavior and Human Decision Processes, 50(2), 179-211.

Alghazo, Y. (2013). The theory of planned behavior and parental involvement: A theoretical framework for narrowing the achievement gaps. International Journal of Science and Research, 5(4), 570-572. 
Ajzen, I. (1991). The theory of planned behaviour. Organizational Behavior and Human Decision Processes, 50, 179-211.

Avvisati, F., Besbas, B. and Guyon, N. (2010). Parental Involvement in School: A Literature Review. Revue d'économie politique, 5(120), $759-778$

Avvisati, F., Gurgand, M., Guyon, N., and Maurin, E. (2014). Getting parents involved: A field experiment in deprived schools. Review of Economic Studies, 81(1), 57-83.

Bagozzi, R. P., and Yi, Y. (1988). On the evaluation of structural equation models. Journal of the Academy of Marketing Science, 16(1), 74-94.

Bandura, A. (1977). Self-efficacy: Toward a unifying theory of behavioral change. Psychological Review, 84(2), 191-215.

Bandura, A., Adams, N. E., Hardy, A. B., and Howells, G. N. (1980). Tests of the generality of self-efficacy theory. Cognitive Therapy and Research, 4, 39-66.

Bracke, D., and Corts, D. (2012). Parental involvement and the theory of planned behavior. Education, 133(1), 188-201

Byrne, B. M. (2013). Structural equation modeling with LISREL, PRELIS, and SIMPLIS: Basic concepts, applications, and programming. Psychology Press.

Chin, W. W. (1998). The partial least squares approach to structural equation modeling. Modern Methods for Business Research, 295(2), 295-336.

Chin, W. W., Marcolin, B. L., and Newsted, P. R. (2003). A partial least squares latent variable modeling approach for measuring interaction effects: Results from a Monte Carlo simulation study and an electronic-mail emotion/adoption study. Information Systems Research, 14(2), $189-217$.

Cho, S., and Han, S. (2004). Development of inventories for initial identification of gifted children. Seoul, Korea: Korean Educational Development Institute

Chowa, G. A., Masa, R. D., and Tucker, J. (2013). The effects of parental involvement on academic performance of Ghanaian youth: Testing measurement and relationships using structural equation modeling. Children and Youth Services Review, 35(12), 20202030.

Donkor, A. K. (2010). Parental involvement in education in Ghana: The case of a private elementary school. International Journal about Parents in Education, 4(1), 23-38.

Donkor, A. K., Issaka, C. A., and Asante, J. (2013). Cultural Practices and Education in Ghana: The Effects of Traditional Culture on Parental Involvement in Education. Research on Humanities and Social Sciences, 3(7), 110-121. 
Eisenberg, N., and Wolchik. S. A. (1992). Parental values, reinforcement, and young children's prosocial behavior: A longitudinal study. Journal of Genetic Psychology, 153(1), 19-36.

Epstein, J. L., \& Sanders, M. G. (2002). Family, school, and community partnerships. Handbook of parenting: Vol. 5. Practical issues in parenting, 407-437.

Epstein, J. L., Sanders, M. G., Simon, B. S., Salinas, K. C., and Voorhis, F. L. (2012). School, Family, and community partnerships: Your Handbook for Action (2nd Ed.). California: Crown Press, Inc.

Fornell, C. and Larcker, D. (1981). Evaluating structural equation models with unobservable variables and measurement error. Journal of Marketing Research, 18(1), 39-50.

Ghana Education Service (2019, March 2). Ghana Education Service Act, 1995 (Act 506). from https://bcp.gov.gh/acc/registry/docs/GHANA\%20EDUCATION\%2020SERVICE\%20 ACT,\%201995\%20(ACT\%20506).pdf

Ghana Statistical Service (2019, February 20). Ghana Living Standard Survey Round 6 (GLSS6), Main Report. Retrieved from https:// statsghana.gov.gh/gssmain/fileUpload/Living\%20 conditions/ GLSS6_Main\%20Report.pdf

Ghana Statistical Service (2019, February 20). 2015 Labour Force report Retrieved from http://www2.statsghana.gov.gh/docfiles/ publications/Labour_Force/LFS\%20REPORT_fianl_21-3-17.pdf

Green, C. L., Walker, J. M. T., Hoover-Dempsey, K. V., and Sandler, H. M. (2007). Parents' motivation for involvement in children's education: An empirical test of a theoretical model of parental involvement. Journal of Educational Psychology, 99(3), 532-544.

Gyamfi, K., and Pobbi, M. A. (2016). Parental Monitoring and Child Performance in Ghana, Journal of Education and Practice. 7 (21), 33-41.

Gyamfi, K., and Pobbi, M. A. (2018). Effect of Parental Discussion on Child Performance: A Structural Equation Approach. Journal of Education and Practice, 9(23), 120-130.

Hair, J. F., Black, W. C., Babin, B. J., Anderson, R. E., and Tatham, R. L. (2006). Multivariate data analysis. New Jersey, NJ: Prentice Hall.

Henseler, J., Ringle, C. M., Sarstedt, M. (2012). Using partial least squares path modeling in international advertising research: Basic concepts and recent issues. In S. Okazaki (Ed.), Handbook of research in international advertising (pp. 252-276). Cheltenham: Edward Elgar.

Jeynes, W. H. (2007). The Relationship between Parental Involvement 
and Urban Secondary School Student Academic Achievement: A

MetaAnalysis. Urban Education, 42 (1), 82-110.

Jeynes, W. (2011). Parental Involvement and academic success. New York: Routledge.

Miksic, M. Y. (2015). Parent Involvement: Theory, Practice, and Head Start. The Role of Social Capital, Spring.

Mungai, D. N. (2015). Relative Contribution of Different Levels of Parental Involvement to Primary School Readiness in Preschool Pupils in Nairobi County. Journal of Education and Practice. 6,(29), 74-80.

Nyarko, K. (2011). Parental school involvement: The case of Ghana. Journal of Emerging Trends in Educational Research and Policy Studies, 2(5), 378-381.

Perry, A., and Langley, C. (2013). Even with the best of intentions: Paternal involvement and the Theory of Planned Behavior. Family Process, 52(2), 179192.

Patrikakou, E. N., Weissberg, K.P., Redding S., and Wahlberg, H. J. (Eds.) (2000), School-family partnership for children's success, 40-56. New York, Teachers college press.

Plevyak, L. H. (2003). Parent involvement in education: Who decides? Education Digest, 69 (2), 32-39.

Pobbi, M. A. (2020). Parental motivations and involvement: A developing country perspective. European Journal of Education Studies, 7(1), DOI 10.5281/zenodo.3710455

Pryor, J., \& Ampiah, J. G. (2003). Understandings of education in an African village: the impact of information and communication technologies (ethnographic study). Department for International Development.

Ringle, C. M., Wende, S., and Becker, J.-M. (2014). SmartPLS 3.0. Hamburg: SmartPLS. Retrieved from http://www.smartpls.com

Strickland, S. C. (2015). The Effects of Parental Motivations on HomeBased and School Based Parental Involvement. (Doctoral Thesis), Walden University

Uemura, M. (1999). Community participation in education: What do you know? British: World Bank.

Vanderpuye, I. (2013). Piloting Inclusive Education in Ghana: Parental Perceptions, Expectations and Involvement. (Doctor of Philosophy), University of Leeds.

Wold, H. O. A. (1982). Soft modelling: The basic design and some extensions. In K. G. Jo"reskog, and H. O. A. Wold (Eds.), Systems under indirect observation. Causality, structure, prediction: Part II (pp. 1-54). Amsterdam: North-Holland. 
Appendix

\section{PARENT QUESTIONNAIRE}

\section{SECTION A - PARENT'S PERSONAL DATA}

1. Name of Child's School

2. Relationship with child Father [ ] Mother [ ]

Guardian [ ] Other (please Specify)

3. Child's Grade/ Class:

Class 3

$\begin{array}{lcc}\text { (Please tick }(\sqrt{ }) \text { as applies }) \\ \text { [ ] } & \text { Class } 5 & \text { [ ] } \\ \text { [ ] } & \text { Class } 6 & \text { [ ] }\end{array}$

Class 4

[ ] Secondary

[ ] Tertiary

Basic

SECTION B - Motivations for Parental Behaviours

The following are known to be reasons why parent get involved in child education. Kindly rate by ticking $(\sqrt{ })$ your level of agreement with each item as a reason for your involvement in your child's education.

Strongly disagree $=1$, disagree $=2, \quad$ neutral $=3$, agree $=4$, strongly agree $=5$

\begin{tabular}{|l|l|l|l|l|l|}
\hline Attitude and belief & 1 & 2 & 3 & 4 & 5 \\
\hline $\begin{array}{l}\text { I am informed with the progress of the } \\
\text { children when I get involved }\end{array}$ & & & & \\
\hline It is important for their performances & & & & & \\
\hline $\begin{array}{l}\text { My involvement in my child education is } \\
\text { important for their self-confidence }\end{array}$ & & & & \\
\hline $\begin{array}{l}\text { It will improve their attitude towards } \\
\text { learning }\end{array}$ & & & & \\
\hline $\begin{array}{l}\text { it is important for their behaviour in } \\
\text { school }\end{array}$ & & & & \\
\hline $\begin{array}{l}\text { It is valuable for securing their future well } \\
\text { being }\end{array}$ & & & & & \\
\hline Social Norm & & & & & \\
\hline $\begin{array}{l}\text { My relatives expect that I take my child to } \\
\text { school }\end{array}$ & & & & \\
\hline $\begin{array}{l}\text { My neighbours and friends expect that I } \\
\text { take my children to school }\end{array}$ & & & & \\
\hline $\begin{array}{l}\text { My child's teachers expect me to check } \\
\text { homework }\end{array}$ & & & & & \\
\hline $\begin{array}{l}\text { My child's school expect that me } \\
\text { participate in school activities like PTA }\end{array}$ & & & & \\
\hline $\begin{array}{l}\text { My child expects me to get involved in } \\
\text { their education }\end{array}$ & & & & \\
\hline
\end{tabular}




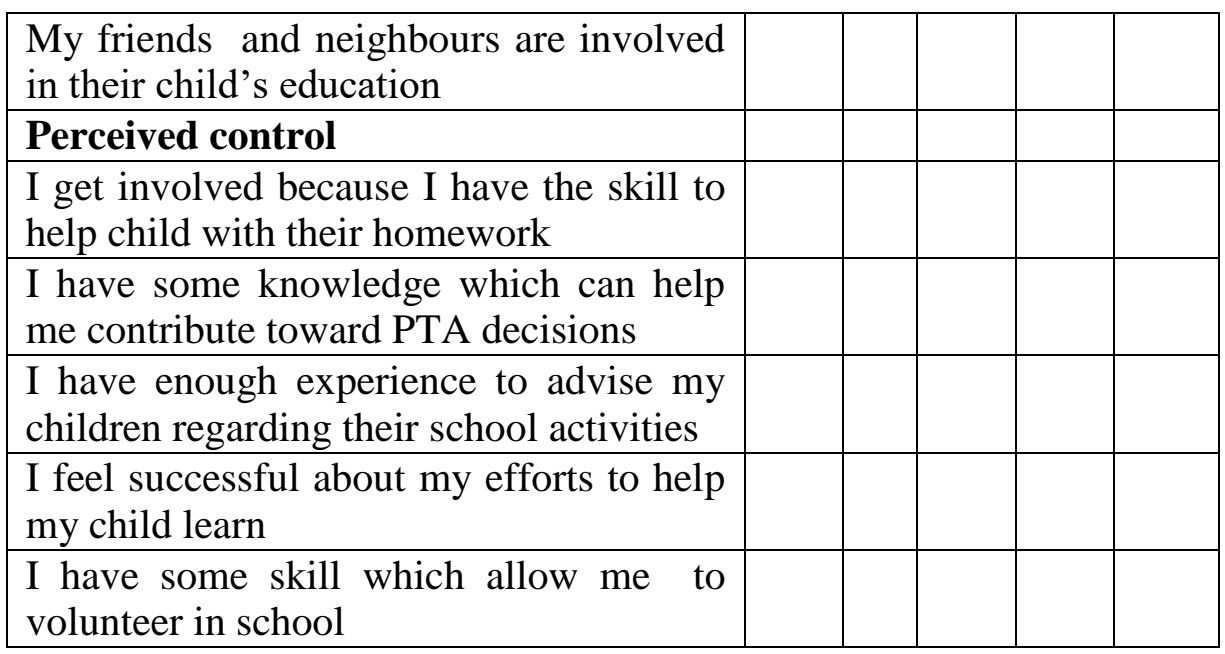

SECTION C- Home-Based and School-Based Involvements

Please indicate by ticking $(\sqrt{ })$ how often you engage in the following Home and School Base activities in relation to your child education.

Never $=1$, rarely $=2$, sometimes $=3$, often $=4$, always $=5$

\begin{tabular}{|l|l|l|l|l|l|}
\hline Home-Based Involvement & 1 & 2 & 3 & 4 & 5 \\
\hline I discuss with my child his/her school-life & & & & & \\
\hline $\begin{array}{l}\text { We as parents discuss plans towards my } \\
\text { education although busy }\end{array}$ & & & & & \\
\hline I show interest in our child's education & & & & & \\
\hline I discuss with my child his/her grades & & & & & \\
\hline I provide for my child's needs & & & & & \\
\hline I pay my child's schools fees & & & & & \\
\hline I ensure my child attends school & & & & & \\
\hline I explain things to my child & & & & & \\
\hline $\begin{array}{l}\text { I buy recommended text books for my } \\
\text { child }\end{array}$ & & & & & \\
\hline I limit my child's playing times & & & & & \\
\hline $\begin{array}{l}\text { I set time for my child's to do their } \\
\text { homework }\end{array}$ & & & & & \\
\hline I select TV programmes for my child & & & & & \\
\hline $\begin{array}{l}\text { I set time to for my child to come back } \\
\text { home from school }\end{array}$ & & & & & \\
\hline I set studying time for my child & & & & & \\
\hline I take my child to children's programs & & & & & \\
\hline $\begin{array}{l}\text { I go with my child to bookstores to buy } \\
\text { books for him/her }\end{array}$ & & & & & \\
\hline I take my child to the library & & & & & \\
\hline School-Based Involvement & & & & \\
\hline $\begin{array}{l}\text { I attend Parent and Teachers Association } \\
\text { meeting }\end{array}$ & & & & & \\
\hline I volunteer to assist in class/in school & & & & & \\
\hline
\end{tabular}




\begin{tabular}{|l|l|l|l|l|l|}
\hline $\begin{array}{l}\text { I communicate with the teachers regarding } \\
\text { child performance }\end{array}$ & & & & & \\
\hline $\begin{array}{l}\text { I participate in other programmes } \\
\text { organised by my child's school }\end{array}$ & & & & & \\
\hline I join my child on their school's field trips & & & & & \\
\hline $\begin{array}{l}\text { I sometimes make contributions towards } \\
\text { the physical development of the school }\end{array}$ & & & & & \\
\hline
\end{tabular}

Thank you 